\title{
Black Desires, White Beauties
}

\author{
MUSHIRA HABIB
}

I wish to be acknowledged not as black but as white . . . who but a white woman can do this for me? By loving me she proves that I am worthy of white love. I am loved like a white man. I am a white man. Her love takes me onto the noble road that leads to total realization . . . I marry white culture, white beauty, white whiteness. When my restless hands caress those white breasts, they grasp white civilization and dignity and make them mine. (Fanon 63)

These insightful lines reveal Frantz Fanon's study of the psycho-sexual desire of the 'man of colour' for the woman of the 'superior race', as explored in his legendary book, Black Skin, White Masks. Though he claims that his observations apply mainly to the 'black' men of Antille, similar states of mind can be unleashed, probing into the colonized minds of all postcolonial men of colour. However, the significance and manifestation of this desire in their lives depend on their circumstances, positions and exposure. The two most renowned novelists from the Caribbean diaspora, V.S. Naipaul and David Dabydeen replicate these findings of Fanon distinctively in their respective novels, A Bend in the River and The Intended. Salim, Naipauls's Asian narrator from the bushes of Africa, forms the image of himself through his relationship with Yvette, whereas Dabydeen's unnamed Guyanese narrator envisions an idealistic position of esteem and power that intends Janet's presence in his life. This paper looks at how these two black men decide a journey of epiphany and self-discovery, holding the hands of these white women; who possess the power to make or break them.

Salim is the displaced postcolonial subject in the heart of Africa; always feeling alienated and conflicted. He is resentful and pessimistic about everything around him throughout the book, but does not seek a way out for himself actively. The novel awaits his progress and success that is not achieved and he seems to be trapped within a continuous halo of dissatisfaction and despair. He becomes the embodiment of the vacuum Naipaul describes in the very first line of the novel: 
"The world is what it is; men who are nothing, who allow themselves to become nothing, have no place in it" (Naipaul 3).

This statement by Naipaul echoes Fanon's claim about the position of a black man in the world, grounding himself in a state of non-existence and disillusionment. Fanon believes that the black man dwells in this condition eternally, without any possible escape. Therefore he writes:

There is a zone of nonbeing, an extraordinarily sterile and arid region, an utterly naked declivity where an authentic upheaval can be born. In most cases, the black man lacks the advantage of being able to accomplish this descent into a real hell. (Fanon 8)

The identity of the narrator of The Intended is lost to such an extent that Dabydeen does not even assign him a name. He appears to be a pro-active, ambitious young man, striving to become white or at least being accepted by the whites as someone worthier than the rest of his own race. Unlike Salim though, he eventually reaches his destination and recalls his life before going to Oxford-his ideal destination. However, his life in Oxford remains unfolded to the readers; whether the place and the education he intended to receive all his life were satisfactory or not, cannot be seen in the novel. But what becomes evident is his success of becoming what he had always intended to become-a writer. So, his wish to rise above his racial aspirations comes true. His desire for this height can be referred back to Fanon as he wrote, "The black is a black man; that is, as the result of a series of aberrations of affect, he is rooted at the core of a universe from which he must be extricated" (Fanon 8).

For both these narrators, Fanon's assumption about an identity crisis, as well as a complexity of mind, is reflected. They are unsure of themselves, their circumstances and visions. Fanon writes:

If there is an inferiority complex, it is the outcome of a double process:

--primarily, economic; 
--subsequently, the internalization-or, better, the epidermalization-of this inferiority. (11)

As quoted at the beginning of this paper, both these 'black' men engage themselves with white women, believing to get upheld by them. Though Yvette and Janet play different roles in Salim's and the unnamed narrator's lives, similar emotions and expectations can be traced in these men, and their desire for the white women keeps echoing Fanon's findings about 'the black man and the white woman'.

Salim is shown to be thoughtful throughout the novel. So, he himself can interpret his relation to Yvette and reflect upon his emotions. The readers that await a radical event in Salim's life expect his affair to bring that climax to his story. But from the very beginning, it is made clear that Salim was not fascinated by Yvette alone; there was a deeper attachment that he wanted to achieve through her - as a representative of the white culture, she becomes a tool for an ascent toward whiteness. His first meeting to Yvette is not emphasized as a personal charm, but as part of a greater illusion. We find Salim to be completely mesmerized by the entire mood of the party as he admits:

Later I saw her dancing, watched the movements of her legs, her shoes; and such a sweetness was released in me that I felt I had recovered a part of myself I had lost. I never looked at the girl's face, and it was easy in the semi-gloom to let that remain unknown. I wanted to sink into the sweetness; I didn't want anything to spoil the mood. (Naipaul 147)

Here, Salim is awed by another white woman, whose face is not significant. Her skin colour, the structure of her body and her white postures fascinate Salim. His internal thoughts about the party are also revealed as he mentions:

What Indar told me brought the President closer. At the same time it showed me how far away I, and people like me, were from the seat of power. Considering myself from that distance, I saw how small and vulnerable we were; and it didn't seem quite real that, dressed as I was, I should be strolling across the Domain after dinner to meet people in direct touch with the great. It 
was strange, but I no longer felt oppressed by the country, the forest and the waters and the remote peoples - I felt myself above it all, considering it from this new angle of the powerful. (Naipaul 145)

This thread that Salim keeps drawing to Raymond and then the President through Yvette is recurrent throughout the novel. Immediately, we know that she does not attract him in isolation, but her position in Africa is inseparable from her image for Salim. He repeatedly mentions how she was a surprise to him from the beginning. He even introduces Yvette as an additional treat in the party. He writes:

From what Indar had said I had expected that Raymond and Yvette would be middle-aged. But the lady - in black slacks in some shiny material - who came to meet us after the white-jacketed boy had let us in was young, in her late twenties, near my own age. That was the first surprise. The second was that she was barefooted, feet white and beautiful and finely made. (Naipaul 146)

This evening appeared as an exotic escape from the monotony of his life in Africa, which lacks any emotion or passion. The party seemed to be something incredible, unreal for him-a life he had never seen before, pleasures unaware of existence. He thinks:

All my adult life I had looked for release in the bars of the town. I knew only women who had to be paid for. The other side of the life of passion, of embraces freely given and received, I knew nothing of, and had begun to consider alien, something not for me. (Naipaul 147)

Salim, neutral in all his political judgments, showing no patronage to the whites, suddenly is shown to be obsessed with the 'whiteness' that the party spread all around him. He is seen to be carried away by the white feet, white steps and white music, as if he got lost in the charm of all of it. He reckons that all of it was "too much to contemplate" (Naipaul 148).

An unaware desire for grabbing the whiteness and the power it carries along, possesses Salim. All his life, he refused to pretend to be happy in life, to compromise with circumstances and assume the role of being in charge of life. But now he wanted to pretend to be content as he himself remarks: 
It was better to pretend, as I could pretend now. It was better to share the companionship of that pretence, to injustice and imminent death and consoled ourselves with love. Even before the songs ended I felt I had found the kind of life I wanted; I never wanted to be ordinary again. (Naipaul 149)

While Indar was distressed by the party, Salim was uplifted and full of spirits. When Indar finally opened up to him as a close friend after all the distance between them, instead of sympathizing with him, Salim kept thinking of the party, and of Yvette. He confesses without any regret:

I thought of Yvette, all at once brought nearer by this tale of her husband's distress. I went over the pictures I had of her that evening, ran the film over again, so to speak, reconstructing and reinterpreting what I had seen, recreating that woman, fixing her in the posture that had bewitched me ... (Naipaul 162)

Salim's unpronounced jealousy about Indar's life, the insecurity that Indar posed to his life is again exposed through Yvette. Indar is like an alter-ego for him, who has been his closest source of knowledge about life outside Africa, education and racial politics abroad. Indar was also the person, who introduced him to the whites in Africa, especially Raymond and Yvette. But Salim even doubts his relationship with Yvette thinking:

I had seen Indar and Yvette together many times, but never in such a domestic relationship. For a dislocating moment the thought came to me that they were going away together. (Naipaul 189)

It is ironic how Indar leaves Salim with Yvette, acting as a catalyst in their relationship. One can also doubt if their relationship could grow in the presence of Indar or not. Indar leaves them the space to interact with and come close to each other. Salim grasps that opportunity unknowingly and describes his first outing with Yvette as:

I had had no experience of dealing with a woman like this, no experience of language like this ... to a man of my background, (it) was slightly frightening and, for that reason, bewitching. (Naipaul 197) 
Gradually, the closer he gets to Yvette, the closer he feels to the position of power, to the life he assumes Raymond to have. Every detail into Yvette's personal life made him feel intimate not to her, but her aura as a whole. He innocently puts it as:

To see the room like this, as Yvette lived in it every day, to add my knowledge of Raymond's position in the country, was to catch her unawares and get some idea of her housewifely ordinariness, some idea of the tensions and dissatisfactions of her life at the Domain, which had until then seemed so glamorous to me. It was to fear to be entangled with her and this life of hers; and it was to be surprised and relieved at the disappearance of my fantasies. But relief and fear lasted only until she came in. The surprise then, as always for me, was herself. (Naipaul 199)

His first sexual intercourse with a white woman leaves him spellbound after all his years of monotonous sexual acts with African maids lacking the pleasure a white woman had to offer. It not only refreshed his body, but also his soul, as he felt so energized that he could even play squash afterwards. All his senses responded to Yvette newly and he felt "blessed" and "remade". He shares:

But I felt now as if I was experiencing anew, and seeing a woman for the first time. I was amazed that, obsessed with Yvette as I had been, I had taken so much for granted. The body on the bed was to me like the revelation of woman's form. (Naipaul 203)

The physical pleasure was overpowered by the visual satisfaction he was getting looking at Yvette's white body with its white textures. That body becomes like the virgin lands the colonizers wished to ravish. Salim's unconscious desire to possess that power of conquest gets exposed as he says:

The wish that came to me-consuming the anxiety about letting myself down-was the wish to win the possessor of that body, the body which, because I wished to win its possessor, I saw as perfect, and wanted continuously, during the act itself, to see, holding myself in ways that enabled me to do so, avoiding crushing the body with my own, avoiding that obliteration of sight and touch ... the sexual act became for me an 
extraordinary novelty, a new kind of fulfillment, continuously new. (Naipaul 203)

Salim's repetition of the word 'white' in this description hints at his state of mind that was hidden for all the years before. He finds a new self and enters a zone of self-realization that was unknown to him for so long. He discovers the Salim, who wants to be white, or at least, to be as powerful as the whites. He writes:

In that room with the window panes painted white, a white that now glowed with the late afternoon light ... I felt refreshed, revitalized; my skin felt new ... It was like discovering a great, unappeasable hunger in myself. (Naipaul 204)

After that first wave of astonishment passed off, another journey towards his 'heart of darkness' began. Unfolding the mysteries of Yvette and Raymond's lives, he came closer to his own hollowness that he ignored to accept so far. When his business suffers the loss of one whole day, he reflects, "I had my first alarm about myself, the beginning of the decay of the man I had known myself to be" (Naipaul 207).

Digging into the unleashed parts of Yvette's life, Salim finds himself to be tangled in the process. He realizes that just the way Yvette was not a woman that attracted him on her own, he also stood for something else in her life. He was perhaps an escape for her from the busy, eventful life. Just as she found Raymond to be an escape from her former life, Salim was an adventure in her present life. Hence he laments:

To Yvette, inexperienced, from Europe, and with her own ambitions, he must have glittered. She would have been misled by her ambitions, much as I had been by her setting, in which I had seen such glamour. Really, then, we did have Raymond in common, from the start. (Naipaul 211)

Poor Salim is further mistaken in looking too much into Yvette's distresses. He found her life to be as hollow as his own. He knew that while he thought she would uplift his position in life, she was entrapping him into her own miseries. Then he thinks: 
And failure like that wasn't what I would have chosen to be entangled with. My wish for an adventure with Yvette was a wish to be taken up to the skies, to be removed from the life I had-the dullness, the pointless tension, 'the situation of the country'. It wasn't a wish to be involved with people as trapped as myself. (Naipaul 215)

Earlier, Salim thought that by getting closer to the 'Big Man', he will gain power. Now he knew that getting closer to him only lets one serve him closely. No one gets benefited in these encounters, except the President himself. What he refused to do for all these years, that is to support the whites in Africa, was what he was participating in unknowingly. He hates to confess:

Through Yvette I was bound to Raymond, and through Raymond I was bound more closely than ever to the fact or the knowledge of the President's power ... we all were serving him. (Naipaul 216)

All the physical satisfaction, as well as Yvette's desire for Salim, did not remain empowering anymore. Salim finds himself powerless as never before; passive and emasculated. He wanted to be the adventurer, but became a pawn of Yvette's adventure himself. He admits:

All my self-esteem came from being Yvette's lover, from serving her and pleasing her in the physical way I did. That was my pride. It was also my shame, to have reduced my manhood just to that. (Naipaul 231)

Salim is crushed by a sense of self-pity and guilt. He loses his significance that he used to be proud of. He wonders, "Was I possessed by Yvette? Or was I-like Mahesh with his new idea of what he was - possessed by myself, the man I thought I was with Yvette?" (Naipaul 236).

The expected adventure was becoming a suffocating routine, from which he needed to be rescued now. The glittering images of his romance faded out completely when he states: 
The first days without Yvette, the first days of solitude, subsiding excitement and clear vision, were always a relief. I could even pretend that I was a free man and that it was possible to go without her. (Naipaul 252)

Then Salim realizes his ultimate mistake of assuming Yvette to be trapped, helpless and wasted. She was still full of possibilities and her life was not as miserable as Salim had believed it to be. Her assertion of the excitements Raymond brought to her life and their plans to move away terrorized Salim. He reflects, "My error: I was too ready to see her as someone lost". (Naipaul 257)

What is prominent here is the insight into Salim's desire. By now, the readers tend to start asking, if Salim wished to be uplifted by Yvette, or did he intend to pull her down with himself. All his raw emotions start to come out one after another, that were perhaps buried in some corner of his mind so far. He feels devastated as he writes, "Affection, just before betrayal. And I had been in tears" (Naipaul 256).

Finally, Salim shocks all the readers, doing something so unexpected and violent that it changes his image completely. He tries to intimidate Yvette by applying force first and then spitting on her, when she does not surrender. This shameful act questions Salim's perception of himself: is he any better than the views he has of the Africans from the bushes? The answer can perhaps be similar to Marlow's investigation in Heart of Darkness, where Kurtz was someone Marlow could become and that was the revelation to his own 'heart of darkness'.

Another way of interpreting this barbaric act could be Lucy's consolation in Coetzee's Disgrace, where she thought that the rape committed on her was a revenge of history. The innumerable rapes of the black slaves are returned by the black men through these violent outrages against the white women. Moreover, if we consider Yvette as Salim's self-reflection, then the rage against himself can be pacified to some extent as the spitting then targets his own self. Perhaps that is why he is so disturbed and confesses to Metty, "I couldn't do anything with her. I didn't want her, I didn't want her. That is what I can't bear. It's all gone" (Naipaul 258). 
It could also be the 'violent overthrow' that Fanon predicts out of the black men's reaction to centuries of oppression in The Wretched of the Earth. Salim's self realization and exposure to the hollowness of the white society can also be compared to Pip's experience in Great Expectations, where getting closer to the gentlemen made him realize their emptiness and his own worth. However, Salim does not find his own place by the end of the novel. His sudden change in circumstances also gives a hint towards Yvette's power. Losing her, Salim lost his place in the bushes of Africa as well. In other words, the unwillingness to become white displaces him forever and he cannot remain an Asian among the blacks either; he keeps floating. However, leaving the 'Domain' towards a future of possibilities can always be an interpretation of the novel.

On the other hand, Dabydeen's narrator's involvement and experience with the white woman is very different from Salim's as are his age, background, conditions and visions. Salim consciously kept himself away from the grasp of a colonized mind that dreams of becoming white. But the narrator in The Intended is conditioned by his Guyanese community to idealize the whites and the white culture. He was taught to regard 'becoming white' as the only release from the 'horror' of his enslaved background. Therefore, the presence of Janet in his life has a greater significance as she becomes his only encounter with the mainstream whites, who have been his idols since childhood. Janet's arrival in his life is introduced ironically from the beginning as Dabydeen writes, "I caught my reflection in the water, waving, mocking. Another face appeared, and I looked up to see Janet" (Dabydeen 115).

Janet's first interaction with him is also symbolic as she invites him on a journey saying, "Come and ride with me ..." (Dabydeen 116). She takes him on a ride of life indeed, making him fantasize a life that he wishes to be a part of. With her, he wants to presume a distant role from his background and reality. Therefore, he writes, "When she asked me about Guyana my mind went blank. It was somehow impossible to talk about Albion Village ..." (Dabydeen 120).

Margery Fee, in her article, "Resistance and Complicity in David Dabydeen's The Intended", writes, "Two emotional relationships central to the narrator's struggle to 
construct an identity for himself are those he forges with the white, upper-class Janet and with Joseph". She finds the narrator to be trapped between these two poles, where Janet symbolizes what he desires to achieve and Joseph represents his fear of falling back.

The narrator tries to impress Janet in ways that he finds to be intelligent, bright and witty. He even cleans up his whole room before her arrival and spends even the last penny to buy cakes and biscuits for her. He then admits, "I wish I were important, somebody, instead of being drowned in a sense of orphaned neglect. I hoped she was suitably impressed by the array of books at least" (Dabydeen 121). Fanon had rightly envisaged this tendency of the black man in Black Skin, White Masks, saying, "Black men want to prove to white men, at all costs, the richness of their thought, the equal value of their intellect" (Fanon 10).

The sexual desire the boy feels towards Janet initially is initiated by his friends' provocations like Patel or Shaz. But he is in fear of failing to please her or of doing something she would not appreciate. He recalls:

I wondered whether she too wanted to be degraded, whether she really wanted me to stop talking, and to pounce on her instead, smearing blackness over all that genteel Englishness. (Dabydeen 169)

But the narrator represses the desire immediately, finding it to be 'improper', so early at a stage of their relationship. On the contrary, he lusts for Monica, who he finds inappropriate to imagine himself to be in a relationship with. But his detailed observation of her exposes his black desire for the white 'whore'. He writes:

The two of them were complete opposites: Janet had a gentle manner and voice, she wore skirts and dresses which gave a softness to her appearance; Monica was firm-breasted, her hair cropped in an aggressive way, and she wore tight-fitting jeans and sexy ankle boots. She smelled of perfume, chewing gum and rubber. Even with her clothes on she had the same tempting sexuality as the models in Shaz's magazines. (Dabydeen 171) 
Monica's objectified description in his eyes is similar to his favourite white doll's account that he recalls as a fantastic body that used to arouse him in his childhood. He describes his feeling as:

The curves of her naked feet aroused me ... I stood there gazing upon her body, and I felt my fingers fumbling to pull down her white slip to discover what lay underneath. It was beautifully white and smooth, hairless, not like Ma's ..." (Dabydeen 227)

But Dabydeen's narrator never considers describing Janet in those terms. He looks up to her as someone beyond his reach and she seems 'proper' and 'pure'. Looking at her family photographs makes him yearn for that life, as he regards it as the ideal place to be in: ". . . I wished I belonged to her family and the village she came from with all its protections and confident virtues" (Dabydeen 169).

However, he finally attempts mating with her stating that "Patel's talk of sex and of white women gladly doing it for money emboldened me. I wanted her" (Dabydeen 202). At the same time, he was scared and worried about his first encounter with her. He mentions, "I drew the curtains to hide my fear . . ." (Dabydeen 203).

While getting into bed with her, he gets overwhelmed by the pleasure and his newly formed sense of manhood. He says with pride:

Everything was proceeding so smoothly that I was already filled with a sense of manly accomplishment: my heart stopped beating wildly and a strange calm seized me, as if such love-making had always been within my capacity. (Dabydeen 203)

Fee looks at his failure to satisfy Janet more deeply than as a first attempt of sexual discourse. She thinks:

Janet also becomes symbolic both of the alma mater and of its gatekeepers quite explicitly, shortly after the narrator attempts to penetrate her, but finds the entrance "unmanageably small". He does not attempt to rape this Miranda, nor can he even make love to her. He is symbolically represented 
as not yet her equal. The text awaits his transformation by Oxford just as he does.

The narrator's inability to establish manhood over the white woman can be referred back to Fanon again; as he said, "At the risk of arousing the resentment of my colored brothers, I will say that the black is not a man" (Fanon 8).

The whole scene after their unsuccessful sexual act becomes symbolic of their positions in life, where Janet remains calm and peaceful and the narrator becomes nervous and disappointed with himself. Janet tries to ease his condition in consoling ways that can also be read ironically. She even tells him, "Start apologising" (Dabydeen 205).

Fee writes, "Janet seems unruffled, however, and asks him when his interview is at Oxford and what he will talk about: "Pretend I'm the board of scholars and you are sitting before me" (Dabydeen 205). She has quickly transformed herself from passive virgin to dominant mistress, taking on the role of the gatekeeper of white culture. Indeed, her class background and her colour, if not her gender, entitle her to this culture almost by right".

The narrator's relation with Janet adds to his ambitions and gives new meanings to his being. He awaits his transformation in Oxford to prove himself extraordinary to her and her family. Fee finds the parting words of Janet as another scope of intended irony. She points out that Janet plays a critical role in the formation of the narrator's identity, as well as the symbolic representation of the white culture in the novel. She adds:

As she leaves, she smilingly and ironically says, "Well, do your best in Oxford and make sure you get in this time". Here, although she has been given her own voice, one that reveals her originality, wit, and power, she is clearly also being "used" for artistic reasons in the narrative.

Amidst all these aspirations, the unnamed narrator sleeps with Monica and seems to change all of a sudden. The sexual satisfaction with his desired white woman seems to calm him down. He not only starts priding himself, but also his 
friendship with Shaz, who gifted Monica to him to "take on the intellectual challenge of Oxford" (Dabydeen 221).

Earlier, all the demeaning and ironic words of Janet never made him bother about his position in her life. He remarks how he felt when she was trying to prepare him for Oxford as, "She turned me round again and again, screwing up her eyes and peering intently. I felt like one of Shaz's whores, or a slave on an auction block" (Dabydeen 243). Fee remarks on his comment that "With her, he is feminized, objectified, infantilized and sexually ashamed. This is the effect of the white culture she symbolizes on the black Other".

When the narrator calls Janet everything he ever intended, she becomes one with the white culture, English glory and education. But blurting it out suddenly, Salim feels exhausted and wasted. At the same time, he realizes her position in his life and reflects upon his emotions about her so far. The illusion of a pure, innocent love is broken in front of his internal desires of possessing her and becoming a part of her white life. Fee thinks, "As the novel draws to an end, the narrator begins to see his relationship with Janet in less idealistic terms. When he blurts out his desire - "but you are fragrant, you are everything I intended," - he realizes how his feelings for her have not, in fact, been intended, but have been forced by his 'plain needs' and 'weakness'".

This realization doubts their relationship to the core and the narrator gets reminded of Patel's words. Fee writes, "Patel puts it more crudely: "Just because you ain't got a mother don't mean that England will mother you, you stupid mother-fucker. . Why don't you grow up and be yourself instead of mourning for white pussy?"'"

The self-discovery also left him in doubt of his potentials and inner wishes. His ambition of becoming 'white' also gets shaken as he perhaps starts wondering what he has 'intended' in his life. Therefore, he admits:

I suddenly felt old and tired and done for...I didn't want to go anywhere anymore. I didn't want to be born time and again. I didn't want to be an eternal, indefinite immigrant. I wanted to get off. (Dabydeen 243) 
This momentary apprehension about the foundation of his identity and aim foregrounds the attachment of Janet to his dreams. But as we get to see the narrator recalling his journey to Oxford after becoming a writer, we can put the pieces together and deduct that he did not go back looking for Janet. Once he went outside Balham, he did not look back as he had foreseen by the end of their last meeting. So, we can say that he weighed his options carefully in life and that led him to his goal, to becoming 'the intended'.

However, Salim could not focus on a particular goal and refused to serve the whites. Hence, he got lost in the lot. He begins a journey by the end of $A$ Bend in the River, without knowing his next destination. This disillusionment of Salim can thus be concluded to be claimed as Fanon's prediction, “However painful it may be for me to accept this conclusion, I am obliged to state it: For the black man there is only one destiny. And it is white" (Fanon 10). The Intended allows its narrator that destiny, where Naipaul rejects it for Salim, portraying him as the ultimate homeless postcolonial subject with no identity and no direction in life to rely on. Finally, it can be said that for the unnamed narrator of Dabydeen, Fanon becomes the forefather, who foretold his desires about the white woman and culture. Salim, being an Asian and refuting any other cultural identity, does not react to the white woman following each footstep of Fanon's black men; thus never settling anywhere. 


\section{Works Cited}

Coetzee, J. M. Disgrace. New York: Penguin, 2000. Print.

Conrad, Joseph. Heart of Darkness. New York: New York, 1999. Print.

Dabydeen, David. The Intended. London: Vintage, 2000. Print.

Fanon, Frantz. Black Skin White Masks. New York: Grove Press, 1967. Print.

---. The Wretched of the Earth. New York: Grove Press, 2004. Print.

Fee, Margery. "Resistance and Complicity in David Dabydeen's The Intended." New

Voices in Caribbean Literature, ed. Kenneth Ramchand. ARIEL 24.1 (1993): 107-26.

Reprinted in "The Art of David Dabydeen." Ed. Kevin Grant. Leeds, UK: Peepul Tree, 1997. 67-88. Print.

Naipaul, V.S. A Bend in the River. London: Picador, 2002. Print. 